should be correlated with our finding that TdT activity is also associated with increased survival and remission rates in acute non-lymphocytic leukaemia. We should emphasise that the TdT activity in our patients was low, which indirectly rules out that some with acute lymphocytic leukaemia had been misdiagnosed as having acute non-lymphocytic leukaemia. This is also supported by cytochemical and morphological analysis. The possibility still exists, however, that increased TdT activity indicates the presence of two blast populations, one lymphoid TdT-positive and a second myeloid or monocytic TdT-negative, as has been described by Mertelsmann et $a l .{ }^{15}$ We thus conclude that measurements of glucocorticoid receptor concentrations and TdT activity contribute partially independent prognostic information. When both are decreased a group of patients with a much decreased survival is identified.

In view of our findings we think that measurement of glucocorticoid receptor concentration and TdT activity should be considered in the design of future prospective studies of acute non-lymphocytic leukaemia.

This work was supported by grants from the Swedish Cancer Society, Karolinska institutets fonder, and Magnus Bergwalls stiftelse.

\section{References}

${ }^{1}$ Hoffbrand A, Ganeshaguru K, Janossy G, Greaves MF, Catovsky D, Woodruff RK. Terminal deoxynucleotidyl-transferase levels and membrane phenotypes in diagnosis of acute leukaemia. Lancet 1977;ii : 520-3.

2 Ellis RB, Rapson NT, Patrick AD, Greaves MF. Expression of hexosaminidase isoenzymes in childhood leukemia. $N$ Engl f Med 1978; 298:476-80.
${ }^{3}$ Marcus SL, Smith SW, Jarowski CI, Modak MJ. Terminal deoxyribonucleotidyl transferase activity in acute undifferentiated leukaemia. Biochem Biophys Res Commun 1976;70:37-44.

4 Marks MS, Boltimore D, McCaffrey R. Terminal transferase as a predictor of initial responsiveness to vincristine and prednisone in blastic chronic myelogenous leukaemia. $N$ Engl f Med 1978;298:812-4.

${ }^{5}$ Quagliata C, Gaig D, Conklyn M, Silber R. Studies on the lymphocyte 5 'nucleotidase in chronic lymphocytic leukaemia. Infectious mononucleosis, normal subpopulations and phytohemaglutinin stimulated cells. Cancer Res $1974 ; 34: 3197-202$.

${ }^{6}$ Meir J, Coleman MS, Hutton JJ. Adenosine deaminase activity in peripheral blood cells of patients with haematological malignancies. $\mathrm{Br} \mathcal{F}$ Cancer 1976;33:312-9.

7 Yarbo GSK, Lippman ME, Johnson GE, Leventhal BG. Glucocorticoid receptors in subpopulation of childhood acute lymphocytic leukaemia. Cancer Res 1977;37:2688-95.

${ }^{8}$ Kaplow LS. Substitute for benzidine in myeloperoxidase stains. Am $\mathfrak{f}$ Clin Pathol $1975 ; 63: 451$.

${ }^{9}$ Löffler H. Cytochemischer Nachweis von unspezifischer Esterase in Ausstrichen Beiträge zur Technik und Ergebnisse im Blutausstrich des Menschen. Klin Wochenschr $1961 ; 39: 1220-7$.

10 Fischer R, Schmalzl F. Úber die Hemmbarkeit der Esteraseaktivität in Blutmonocyten durch Natriumfluorid. Klin Wochenschr 1964;42:751.

${ }^{11}$ Moloney WC, McPherson K, Fliegelman L. Esterase activity in leukocytes demonstrated by the use of naphthol AS-D chloroacetate substrate. f Histochem Cytochem 1960;8:200-7.

12 Bennet JM, Catovsky D, Daniel MT, et al. Proposals for the classification of the acute leukaemias. Br $\mathcal{F}$ Haematol 1976;33:451-8.

13 Burton KA. A study of the conditions and mechanism of the diphenylamine reaction for the colorimetric estimation of deoxyribonucleic acid. Biochem 7 1956;62:315-22.

${ }^{14}$ Lippman ME, Halterman RH, Leventhal BG, Perry S, Thompsson EB. Glucocorticoid-binding proteins in human acute lymphoblastic leukaemic blast cells. $\mathcal{f}$ Clin Invest 1973;52:1715-25.

${ }^{15}$ Mertelsmann R, Koziner B, Ralph P, et al. Evidence for district lymphocytic and monocytic populations in a patient with terminal transferase positive acute leukaemia. Blood 1978;51:1051-6.

(Accepted 10 April 1981)

\title{
Oral contraceptive steroid plasma concentrations in smokers and non-smokers
}

\author{
F E CRAWFORD， D J BACK， M L'E ORME，A M BRECKENRIDGE
}

\begin{abstract}
A study was performed to find out whether the overall rate of metabolism of oral contraceptives is affected by smoking and whether this explains the increased incidence of cardiovascular disease in users of oral contraceptives who smoke. Plasma ethinyloestradiol and norgestrel concentrations in 311 women using oral contraceptives were similar in smokers and non-smokers.

The overall rate of metabolism of contraceptive steroids does not therefore seem to be affected by cigarette smoking.
\end{abstract}

\section{Introduction}

Cigarette smoking is one of the factors implicated in the development of cardiovascular disease in oral contraceptive

\footnotetext{
Department of Pharmacology and Therapeutics, University of Liverpool, Liverpool L69 3BX

F E CRAWFORD, BSC, PHD, postdoctoral fellow

D J BACK, BSC, PHD, lecturer in pharmacology

$M$ L'E ORME, MA, FRCP, senior lecturer in clinical pharmacology

A M BRECKENRIDGE, MSC, FRCP, professor of clinical pharmacology
}

users. ${ }^{1}$ Tobacco smoke contains over 3000 chemicals and some of the constituents (polycyclic aromatic hydrocarbons) are enzyme-inducers. In pharmacokinetic studies the rate of metabolism of some drugs-for example, phenacetin and antipyrine-is increased in cigarette smokers. In contrast, no effect of smoking has been observed on the disposition of other drugs-for example, diazepam and phenytoin. ${ }^{2}$ The metabolism of ethinyloestradiol may be important in relation to toxicity: a metabolite of ethinyloestradiol becomes irreversibly bound to protein of human hepatic microsomes, ${ }^{3}$ and this could be the starting point of an immunological mechanism leading to an adverse reaction. Consistent with this, anti-ethinyloestradiol antibodies have been detected in oral contraceptive users. ${ }^{4}$

The aim of our study was twofold: to find out whether oral contraceptives fall into the group of drugs whose overall rate of metabolism is affected by smoking, and to see whether this might account for the increased toxicity.

\section{Subjects, methods, and results}

We studied 311 women taking oral contraceptives containing $30 \mathrm{\mu g}$ ethinyloestradiol (Eugynon 30, Microgynon, and Ovranette). A blood sample was obtained from each woman, and we recorded the time of the last pill, her weight, age, whether she smoked (and the number of cigarettes per day), and any other medication. Plasma 
Plasma concentrations of ethinyloestradiol and norgestrel in smokers and non-smokers with data grouped for less than 12 hours, 12-15 hours, and 18-19 hours since oral contraceptive taken

\begin{tabular}{|c|c|c|c|c|c|c|c|c|c|}
\hline \multirow[b]{2}{*}{ Measurement } & \multicolumn{3}{|c|}{ Smokers } & \multicolumn{3}{|c|}{ Non-smokers } & \multirow[b]{2}{*}{$t$} & \multirow[b]{2}{*}{$p$} & \multirow{2}{*}{$\underset{t}{\text { Adjusted }}$} \\
\hline & Mean & SD & No & Mean & SD & No & & & \\
\hline \multicolumn{10}{|c|}{ All pills, time $<12$ hours } \\
\hline $\begin{array}{l}\text { Weight }(\mathrm{kg}) \\
\text { Age (years) } \\
\text { Time (hours) } \\
\text { Norgestrel }(\mu \mathrm{g} / \mathrm{l}) \\
\text { Ethinyloestradiol (ng/l) } \\
\text { Log (ethinyloestradiol) } \\
\text { Thiocyanate (mg/l) }\end{array}$ & $\begin{array}{c}58.9 \\
22 \cdot 9 \\
7 \cdot 3 \\
3 \cdot 08 \\
53 \cdot 4 \\
1.58 \\
11 \cdot 2\end{array}$ & $\begin{array}{c}7 \cdot 5 \\
5 \cdot 0 \\
2 \cdot 7 \\
1 \cdot 75 \\
45 \cdot 5 \\
0 \cdot 38 \\
4 \cdot 2\end{array}$ & $\begin{array}{l}19 \\
19 \\
19 \\
19 \\
19 \\
19 \\
19\end{array}$ & $\begin{array}{c}56 \cdot 9 \\
23 \cdot 2 \\
8 \cdot 1 \\
3 \cdot 03 \\
48 \cdot 2 \\
1 \cdot 54 \\
2 \cdot 1\end{array}$ & $\begin{array}{c}5 \cdot 6 \\
4 \cdot 6 \\
3 \cdot 1 \\
1 \cdot 59 \\
45 \cdot 4 \\
0 \cdot 35 \\
1 \cdot 4\end{array}$ & $\begin{array}{l}34 \\
34 \\
34 \\
34 \\
34 \\
34 \\
34\end{array}$ & $\begin{array}{r}1.12 \\
0.21 \\
1.05 \\
0.09 \\
0.40 \\
0.45 \\
11.53\end{array}$ & $\begin{array}{l}\text { NS } \\
\text { NS } \\
\text { NS } \\
\text { NS } \\
\text { NS } \\
* * *\end{array}$ & $\begin{array}{l}0.22 \\
0.07\end{array}$ \\
\hline \multicolumn{10}{|c|}{ All pills, time $12-15$ hours } \\
\hline $\begin{array}{l}\text { Weight (kg) } \\
\text { Age (years) } \\
\text { Time (hours) } \\
\text { Norgestrel ( } \mu \mathrm{g} / \mathrm{l}) \\
\text { Ethinyloestradiol (ng/1) } \\
\text { Log (ethinyloestradiol) } \\
\text { Thiocyanate (mg/l) }\end{array}$ & $\begin{array}{l}57 \cdot 6 \\
25 \cdot 1 \\
13 \cdot 9 \\
2.59 \\
42 \cdot 8 \\
1.43 \\
8 \cdot 8\end{array}$ & $\begin{array}{l}6 \cdot 2 \\
5 \cdot 9 \\
1 \cdot 0 \\
1 \cdot 51 \\
49 \cdot 6 \\
0 \cdot 43 \\
4 \cdot 0\end{array}$ & $\begin{array}{l}58 \\
58 \\
58 \\
58 \\
58 \\
58 \\
58\end{array}$ & $\begin{array}{l}56 \cdot 4 \\
23 \cdot 1 \\
14 \cdot 3 \\
2 \cdot 46 \\
46 \cdot 7 \\
1 \cdot 50 \\
2 \cdot 0\end{array}$ & $\begin{array}{c}7 \cdot 3 \\
3.9 \\
0.9 \\
1.12 \\
49.8 \\
0.42 \\
1.4\end{array}$ & $\begin{array}{l}134 \\
134 \\
134 \\
133 \\
132 \\
132 \\
134\end{array}$ & $\begin{array}{r}1 \cdot 11 \\
2 \cdot 75 \\
2 \cdot 55 \\
0 \cdot 70 \\
0 \cdot 50 \\
1 \cdot 01 \\
17 \cdot 21\end{array}$ & $\begin{array}{l}\text { NS } \\
{ }_{* *}^{*} \\
\text { NS } \\
\text { NS } \\
\text { NS } \\
*_{* *}\end{array}$ & $\begin{array}{l}0.82 \\
1.27\end{array}$ \\
\hline \multicolumn{10}{|c|}{ All pills, time $16-19$ hours } \\
\hline $\begin{array}{l}\text { Weight (kg) } \\
\text { Age (years) } \\
\text { Time (hours) } \\
\text { Norgestrel ( } \mu \text { g/l) } \\
\text { Ethinyloestradiol (ng/1) } \\
\text { Log (ethinyloestradiol) } \\
\text { Thiocyanate (mg/l) }\end{array}$ & $\begin{array}{c}55 \cdot 2 \\
23 \cdot 0 \\
17 \cdot 3 \\
2 \cdot 44 \\
40 \cdot 1 \\
1 \cdot 46 \\
8 \cdot 8\end{array}$ & $\begin{array}{c}6.4 \\
5.5 \\
1.1 \\
1.21 \\
31.9 \\
0.39 \\
3.4\end{array}$ & $\begin{array}{l}21 \\
21 \\
21 \\
21 \\
21 \\
21 \\
21\end{array}$ & $\begin{array}{c}56 \cdot 3 \\
22 \cdot 1 \\
17 \cdot 4 \\
2 \cdot 27 \\
60 \cdot 4 \\
1.48 \\
2 \cdot 0\end{array}$ & $\begin{array}{c}6.9 \\
4.4 \\
1.2 \\
1.16 \\
123.9 \\
0.45 \\
1.3\end{array}$ & $\begin{array}{l}38 \\
38 \\
38 \\
38 \\
38 \\
38 \\
38\end{array}$ & $\begin{array}{r}0.60 \\
0.69 \\
0.19 \\
0.51 \\
0.74 \\
0.18 \\
10.97\end{array}$ & $\begin{array}{l}\text { NS } \\
\text { NS } \\
\text { NS } \\
\text { NS } \\
\text { NS } \\
\text { NS } \\
* * *\end{array}$ & $\begin{array}{l}0 \cdot 71 \\
0 \cdot 22\end{array}$ \\
\hline
\end{tabular}

was separated by centrifugation and analysed for ethinyloestradiol and norgestrel content by radioimmunoassay. As an indicator of the absence or presence and extent of the smoking habit, the concentration of plasma thiocyanate was measured using a simple colorimetric assay. Statistical differences between the means were compared by using unpaired $t$ tests and analysis of covariance.

The table shows subjects grouped according to time since the pill was taken. There was no suggestion of a difference attributable to smoking in the mean ethinyloestradiol concentrations, even when subjected to a logarithmic (base 10) transformation to correct for a positive skew. The adjusted $t$ value was derived from an analysis of covariance with the covariates being weight, age, and time (since the pill was taken). Norgestrel concentrations were not significantly different in the unpaired $t$ test. When consideration was given to the differing amounts of norgestrel in the preparations $(150 \mu \mathrm{g}$ in Microgynon and Ovranette, $250 \mu \mathrm{g}$ in Eugynon), and these data were subjected to analysis of covariance, again there was no significant difference between smokers and non-smokers. In all groups plasma thiocyanate concentrations were considerably increased. There was a similar large interindividual variation in plasma concentrations of ethinyloestradiol and norgestrel in both smokers and non-smokers (ethyinoestradiol: smokers 5-279 ng/l, non-smokers 5-450 ng/l norgestrel: smokers $0 \cdot 44-8 \cdot 0 \mu \mathrm{g} / \mathrm{l}$, non-smokers $0 \cdot 25-5 \cdot 38 \mu \mathrm{g} / \mathrm{l}$ ).

\section{Discussion}

There was no suggestion of a difference due to smoking in plasma concentrations of either norgestrel or ethinyloestradiol, and contraceptive steroids therefore seem to fall into the group of drugs whose overall rate of metabolism is not altered by cigarette smoking. This does not, however, preclude the possibility of an increase in the rate of formation of a minor but potentially toxic metabolite. Gillette ${ }^{5}$ suggested that if under normal conditions the fraction of a drug converted into a reactive metabolite was small, then an enzyme inducer might considerably increase this fraction without any appreciable change in the plasma concentration or half life of the parent compound. Such a mechanism may operate in oral contraceptive users who smoke and hence give an increased incidence of toxicity. At present such a scheme is speculative and there is no firm evidence of a metabolic cause for the smoking-contraceptive steroid interaction.

FEC was supported by Schering AG. We are very grateful to Dr K D Macrae of Charing Cross Hospital, London, for statistical analysis.

\section{References}

${ }^{1}$ Royal College of General Practitioners' Oral Contraception Study. 글 Mortality among oral-contraceptive users. Lancet 1977 ;ii:727-31.

${ }^{2}$ Jusko WJ. Influence of cigarette smoking on drug metabolism in man. Drug Metab Rev 1979;9:221-36.

${ }^{3}$ Bolt H-M, Kappus H, Kasbohrer R. Metabolism of $17 \alpha$-ethinyloestradiol ${ }^{\Phi}$ by human liver microsomes in vitro: Aromatic hydroxylation and $\vec{\oplus}$ irreversible protein binding of metabolites. $\mathcal{F}$ Clin Endocrinol Metab $\stackrel{\infty}{\hookrightarrow}$ $1974 ; 39: 1072-80$.

${ }^{4}$ Beaumont JL, Lemort N, Lorenzelli-Edouard L, Delplanque B, Beaumont V. Antiethinyloestradiol antibody activities in oral contraceptive users. Clin Exp Immunol 1979;38:445-52.

${ }^{5}$ Gillette JR. Toxicological implications of drug metabolism. In: Estabrook $\mathrm{RW}$, Lindenlaub E, eds. The induction of drug metabolism. Stuttgart: Verlag, 1979: 309-25.

(Accepted 24 March 1981)

ONE HUNDRED YEARS AGO

The Rev Joseph Cook, a wellknown American pulpit-orator, has come over to this benighted 3 country to overthrow Huxley, Michael Foster, and other philosophers. The plea for this special mission appears to be that, having attained to $\frac{3}{3}$ an accurate knowledge of scientific research, he is competent to expose the fallacies of men of science. Judging, however, from some extra- $\frac{\rho}{J}$ ordinary statements which this lecturer is reported to have made with $N$ reference to the action of alcohol on the living brain, our modern scientific inquirers may take heart of grace, and rest in peace a little longer. $\mathrm{Mr}$ Cook, in sight of large audiences in the North, poured alcohol on white of egg. After stirring this for a few minutes, he held $N$ the mass up as the representation of a moderate drinker's brain. After a longer interval, the mass, having become hardened, was exhibited as 0 a fair illustration of a drunkard's brain. With lamentable ignorance of the science he professed to know, the reverend lecturer proceeded to state, as a fact, that alcohol hardened the living human brain, leaving $\stackrel{\oplus}{\oplus}$ indelible scars on the cerebrum. The elementary fact that, while ? alcohol hardens dead cerebral substance, in life it induces softening of the brain, is, it must charitably be assumed, unknown to him. Before $\frac{P}{\mathbb{D}}$ public dognatic statements on physiological questions are made, it is $ᄋ$ desirable that lecturers, of whatever profession or country, should, for $\mathbb{Q}$ their own reputation, and for the truth's sake, ascertain the elementary $\bar{\sigma}$ facts, either by personal research or by consulting some competent physiologist. Such prolusions as these cover with ridicule a good 0 cause, which most members of our profession have, we are convinced, deeply at heart, and can only disgust sensible hearers. (British Medical fournal, 1881.) 